\title{
DIFFERENTIAL SENSITIVITY OF PREIMPLANTATION MOUSE EMBRYOS IN VITRO TO OESTRADIOL AND PROGESTERONE
}

\author{
JAY F. KIRKPATRICK* \\ Department of Physical Biology, \\ New York State Veterinary College, \\ Cornell University, Ithaca, New York
}

(Received 7th June 1971)

Steroids of various types have been found to effect structural changes in fertilized mammalian ova. Changes in rat blastocysts transplanted into animals given $2 \mathrm{mg}$ progesterone daily indicated that in fertilized ova this hormone induced dormancy, which, in turn, retarded trophoblast maturation (Dickmann \& DeFeo, 1967). A daily dose of $3 \mathrm{mg}$ progesterone resulted in an abnormally large increase in ovum mass and a failure to elongate among blastocysts from ovariectomized rats (Yasukawa \& Meyer, 1966). The addition of $1 \mu \mathrm{g}$ oestrone prevented these effects.

Fertilized rabbit ova cultured in vitro with varying concentrations of oestradiol-17- $\beta$ showed cleavage inhibition and fragmentation (McGaughey \& Daniel, 1966). In a similar study, various steroids were added to rabbit ova cultured in serum (Daniel, 1964). Addition of $10 \mu \mathrm{g} / \mathrm{ml}$ progesterone to the serum was capable of causing cleavage inhibition. If the ova were removed from the steroid medium, normal growth was resumed. Oestrogen caused small protrusions to appear on the ovum. These cytoplasmic 'blebs' had no organized nucleus and little chromosomal material.

Two-day-old mice ova grown in vitro in medium containing progesterone were unable to develop normally (Whitten, 1957). Few ova survived concentrations of $4 \mu \mathrm{g} / \mathrm{ml}$, mostly due to inhibition of zona herniation. Oestrogens offered no protection from the effects of progesterone.

This investigation was undertaken to determine if there is a differential sensitivity of various aged preimplantation mouse embryos to oestradiol and progesterone. The study utilized more advanced culture techniques in vitro than those used previously in steroid effect studies.

Six-week-old, random bred, White Swiss mice were used for the study. The females were superovulated with 10 i.u. injections of serum gonadotrophin (Equinex, Ayerst) and chorionic gonadotrophin (A.P.L., Ayerst). The injections were given intraperitoneally, separated by $44 \mathrm{hr}$. The females were placed with males, left overnight and removed the next morning and observed for vaginal plugs. Approximately 48 to $50 \mathrm{hr}$ after the chorionic gonadotrophin injection,

* Present address: Department of Biological Sciences, Eastern Montana College, Billings, Montana 59101. 
the embryos were removed for culturing. The females were killed by cervical dislocation and the oviducts were removed and placed in culture medium. The fimbrial end of the oviducts was cannulated and the contents flushed with warmed $\left(37^{\circ} \mathrm{C}\right)$ culture medium. Morphologically normal two-cell embryos were collected with a micropipette, washed in culture medium and placed in groups of ten in the wells of disposable agglutination titre-boards (Linbro Chemical Co.). The embryos from five to ten mice were pooled before transferring them to the culture wells, in order to obtain a random distribution. Each well contained $1.0 \mathrm{ml}$ of Brinster's Medium for ovum culture plus Glucose (Brinster, 1965) covered by $0.1 \mathrm{ml}$ of No. 360 medical fluid (DowCorning Co.). The medical fluid protected the culture fluid from evaporation and subsequent changes in molarity. This medium, which supports the development of two-cell mouse embryos to the blastocyst stage, was sterilized by filtration.

The embryos were kept in a plastic box inside a Boekel desiccating chamber, which itself was inside a gassing incubator maintained at $37^{\circ} \mathrm{C}$. The $5 \% \mathrm{CO}_{2}$ in air culturing atmosphere was delivered continuously throughout the experiment, at a rate of 0.3 litres $/ \mathrm{min}$. Oestradiol-17 $\beta$ (Sigma) and progesterone (Mann) were incorporated into the distilled water which was later used in the culture medium. This procedure avoided the danger of changing molarity of the culture medium, as is the case when adding steroids as a solution. Each steroid was dissolved in $95 \%$ ethyl alcohol and diluted 100 times with distilled water. This resulted in an alcohol concentration of less than $1.0 \%$ which did not appear to be detrimental to the growth of control embryos. All results reported in this paper are based on experiments utilizing a minimum of fifty embryos/experimental group.

TABLE 1

DIFFERENTIAL SENSITIVITY OF EARLY MOUSE EMBRYOS TO OESTRADIOL AND PROGESTERONE

\begin{tabular}{l|ccc}
\hline \multirow{2}{*}{$\begin{array}{c}\text { Stage of } \\
\text { development } \\
\text { when cultured }\end{array}$} & $\begin{array}{c}\text { Percentage of embryos reaching late blastula } \\
\text { stage }\end{array}$ \\
\cline { 2 - 4 } & Control & $\begin{array}{c}\text { Oestradiol }-17 \boldsymbol{\beta} \\
25 \mathrm{mg} / \mathrm{ml}\end{array}$ & $\begin{array}{c}\text { Progesterone } \\
\mathbf{8} \mathrm{mg} / \mathrm{ml}\end{array}$ \\
\hline Two-cell & 85.0 & 0 & 0 \\
Four-cell & 85.0 & $4 \cdot 0$ & 0 \\
Eight-cell & 88.7 & 16.0 & $11 \cdot 0$ \\
Morula stage & 90.0 & 30.4 & 49.7 \\
Early blastula & 98.1 & 81.3 & 71.2 \\
\hline
\end{tabular}

Embryos of varying stages, i.e. two-cell, four-cell, eight-cell, morula stage (sixteen-cell or more) and early blastula, were cultured in medium containing $25 \mu \mathrm{g} / \mathrm{ml}$ oestradiol- $17 \beta$ or $8 \mu \mathrm{g} / \mathrm{ml}$ progesterone. Table 1 indicates the differential sensitivity of the embryos to these concentrations of steroids. Oestradiol caused a noticeable decrease in normal cleavage and after $24 \mathrm{hr}$ in culture, there was degeneration among embryos of the two-cell, four-cell, eight-cell and morula stages. Once the early blastula stage was attained, there was little 
or no detrimental effect. Among developmental stages younger than the early blastocyst cultured in progesterone, there was an increase in cleavage inhibition and degeneration. Progesterone also caused a dark granulation of the zona pellucida among the embryos which were unable to complete development in vitro. Embryo death occurred no later than one cleavage following incubation in the case of both oestradiol and progesterone.

Differential sensitivity indicates a definite trend toward resistance to steroids as the early embryo progresses in development.This may be a result of increase in the membrane surface of the cellular component of the embryos as development proceeds. A previous study (Willmer, 1961) demonstrated that progesterone penetrates into phospholipid layers of membranes so that the methyl ketone end of the molecule penetrates and the ketone is exposed. This exposed ketone has the ability to bind basic protein. The ring four hydroxyl of oestrogen and the ring four end-group of progesterone are also capable of penetration of the membrane, leaving ring one groups exposed. This reaction probably blocks protein synthesis, which in turn is related to mitotic apparatus and chromosome condensation. As development proceeds and surface area increases, the steroid molecules may be distributed too sparsely to block the entrance of necessary protein. The differential sensitivity noted here may also result from a greater ability of the embryo to recover from damage. Since the blastomeres of the preimplantation embryo are totipotent, there exists the possibility of dead blastomeres being replaced by viable ones, while at earlier stages there are no viable blastomeres remaining.

\section{REFERENCES}

BRINSTER, R. L. (1965) Studies on the development of mouse embryos in vitro. I. The effects of osmolarity and hydrogen ion concentration. F. exp. Zool. 158, 49.

DANiEL, J. C., JR (1964) Some effects of steroids on cleavage of rabbit eggs in vitro. Endocrinology, 75, 706.

Dickmann, Z. \& DeFeo, V. J. (1967) The rat blastocyst during normal pregnancy and during delayed implantation including an observation on the shedding of the zona pellucida. F. Reprod. Fert. $13,3$.

McGaughey, R. W. \& Daniel, J. C., JR. (1966) Effect of oestradiol-17 $\beta$ on fertilized rabbit eggs in vitro. 7. Reprod. Fert. 11, 325.

Whrtten, W. K. (1957) The effect of progesterone on the development of mouse embryos in vitro. F. Endocr. 16, 80.

WiLlmer, E. N. (1961) Steroids and cell surfaces. Biol. Rev. 36, 368.

Yasukawa, J. J. \& MEYeR, R. K. (1966) Effect of progesterone and oestrone on the preimplantation stages of embryo development in the rat. F. Reprod. Fert. 11, 245. 